\title{
PERSEPSI TENTANG MATA PELAJARAN IPS BAGI PESERTA DIDIK BERPRESTASI RENDAH (KASUS PADA KELAS VII DI SMP MUHAMMADIYAH PALANGKA RAYA)
}

\author{
Oleh \\ Sinta Kumala Dewi* Diplan** \\ diplan@gmail.com
}

\begin{abstract}
This researcher aims to find out the learning activities of students and find out the perceptions of students about social studies subjects. This study used a descriptive qualitative research approach, which was the subject of this study were 8 students at the Muhammadiyah Middle School in Palangka Raya. Data collection techniques using observation sheets, interviews and documentation. The data analysis technique used is qualitative descriptive analysis. The results of the study found that students with low achievement had negative perceptions of social studies subjects. This is illustrated by: a. The way teachers teach who always asks students to record too much and teachers are less able to approach the students with low achievement. b. Schedule of social studies subjects that are available during the day so that students feel lazy to take social studies subjects.
\end{abstract}

(C) Muhammadiyah University of Palangkaraya

Keywords: Perception, Social Sciences, Low Achievement Students

\begin{abstract}
ABSTRAK
Peneliti ini bertujuan untuk mengetahui aktivitas Belajar peserta didik dan mengetahui persepsi peserta didik tentang mata pelajaran IPS. Penelitian ini menggunakan pendekatan penelitian kualittatif deskriptif, yang menjadi subjek dalam penelitian ini adalah 8 peserta didik di SMP Muhammadiyah Palangka Raya. Teknik pengumpulan data menggunakan lembar observasi, wawancara dan dokumentasi. Teknik analisis data yang digunakan adalah analisis deskriptif kualitatif. Hasil penelitian yang ditemukan bahwa peserta didik yang berprestasi rendah memiliki persepsi negatif terhadap mata pelajaran IPS. Hal ini tergambar dari : a. Cara guru mengajar yang selalu meminta peserta didik mencatat terlalu banyak serta guru kurang mampu melakukan pendekatan terhadap peserta didik yang berprestasi rendah. b. Jadwal mata pelajaran IPS yang ada pada siang hari sehingga peserta didik sudah merasa malas untuk mengikuti mata pelajaran IPS.
\end{abstract}

(C) Universitas Muhammadiyah Palangkaraya

Kata Kunci: Persepsi, IPS, Peserta Didik Berprestasi Rendah. 


\section{PENDAHULUAN}

Pendidikan merupakan hal yang wajib bagi bangsa kita, sebab kita ingin negara kita bisa menjadi negara yang tidak lagi buta huruf melainkan warga negara yang memiliki pendidikan yang jauh lebih bagus dari sebelumnya bahkan jauh lebih luas. Bangsa kita sekarang sudah menganggap bahwa pendidikan sudah sangat penting bagi kecerdasan bangsa, karena dengan adanya pendidikan maka cara berfikir manusia akan jauh lebih bagus dan maju. Dengan mempunyai pendidikan yang sangat cukup memadai maka kita sudah siap untuk bersaing dengan negara asing lainnya.

Dalam Undang-Undang No. 20 Tahun 2003 tentang Sistem Pendidikan Nasional (Bab II Pasal 3) mengatakan fungsi serta tujuan Pendidikan Nasional berfungsi mengembangkan dan membentuk kemampuan serta peradaban bangsa yang bermartabat dalam rangka mencerdaskan kehidupan bangsa, bertujuan untuk berkembangnya peserta didik agar menjadi manusia yang beriman dan bertaqwa kepada Tuhan Yang Maha Esa, berahlak mulia, sehat berilmu, cakap, kreatif, mandiri dan menjadi warga negara yang demokratis dan bertanggung jawab.

Dari isi Undang-Undang No. 20 Tahun 2003 tentang Sistem Pendidikan Nasional (Bab II Pasal 3) di atas maka sudah pasti tujuan dari pendidikan di negara kita adalah untuk mencerdaskan kehidupan bangsa kita. Dengan adanya pendidikan yang sangat mendukung maka negara kita akan selalu dapat melakukan inovasi-inovasi baru untuk memajukan baik untuk masyarakatnya lebih lagi untuk kemajuan bangsa itu sendiri.

Di dalam sebuah pendidikan guru mempunyai berbagai macam cara atau model dalam pembelajaran di dalam kelas. Akan tetapi masih ada beberapa guru yang sering menggunakan metode ceramah saja, dengan hal tersebut sangat berpengaruh pada keaktifan peserta didik. Alangkah lebih baik apabila guru menggunakan beberapa metode, maka guru dapat melihat kemampuan peserta didik dalam merespon pelajaran yang diberikan oleh guru.

Pengertian belajar menurut Slameto (dalam Evelin Siregar dkk, 2010:2) mengatakan bahwa belajar ialah suatu proses usaha yang dilakukan seseorang untuk memperoleh suatu perubahan tingkah laku yang baru secara keseluruhan, sebagai hasil pengalamannya sendiri dalam interaksi dengan lingkungannya. Belajar merupakan proses yang terjadi dalam diri dan disimpulkan dari hasil yang dapat dilakukannya. Dari belajar dapat di identifikasikan 3 persoalan yaitu: 1)input adalah persoalan faktor yang mempengaruhi belajar; 2) proses adalah bagaimana berlangsungnnya belajar; 3) ouput adalah persoalan hasil belajar yang ditujukan dari pengukuran hasil belajar.

Persepsi merupakan anggapan atau pandangan yang ditujukan pada apa yang dilihat, didengar, atau dirasakan oleh indra individu dalam bentuk sikap, pendapat dan tingkah laku. Dengan kata lain juga persepsi yaitu informasi yang diterima dan disimpulkan dalam anggapan-anggapan yang lebih 
bermakna. Konsep persepsi yang dikemukakan Rakhmat (dalam I Made Wirartha, 2006:27) menyatakan bahwa persepsi adalah pengalaman tentang obyek, peristiwa atau hubungan yang diperoleh dengan mengumpulkan informasi dan penafsiran pesan. Selanjutnya persepsi merupakan proses pengorganisasian dan interpretasi seseorang terhadap apa yang diterimanya untuk memberi arti terhadap lingkungannya.

Manusia sebagai mahluk sosial yang sekaligus juga mahluk individual, maka terdapat perbedaan antara individu yang satu dengan yang lainnya. Adanya perbedaan inilah yang antara lain menyebabkan mengapa seseorang menyenangi suatu obyek, sedangkan orang lain tidak senang bahkan membenci obyek tersebut. Hal ini sangat tergantung bagaimana individu menanggapi obyek tersebut dengan persepsinya. Sedangkan menurut Jalaludin Rahmat (dalam Sugiyono, 2007:51) menyatakan bahwa persepsi adalah pengamatan tentang obyek, peristiwa atau hubungan-hubungan yang diperoleh dengan menyimpulkan informasi dan menafsirkan pesan. Dari pendapat ahli dapat disimpulkan persepsi merupakan proses perlakuan seseorang terhadap objek atau informasi yang diterima melalui pengamatan indra yang dimiliki, lalu menjadi anggapan atas apa yang terjadi dengan objek tersebut. Suatu penilaian seseorang terhadap apa yang dilihat dan didengar baik sesuatu yang positif maupun sesuatu yang negatif.

Menurut Banks (dalam Sapriya, 2015:142) mengemukakan bahwa pendekatan mengajar dalam IPS dengan menggunakan inkuiri sosial untuk menghasilkan fakta, konsep, generalisasi, dan teori. Namun tujuan utama inkuiri sosial menurutnya adalah untuk membangun teori. Sedangkan menurut Somantri (dalam Sapriya, 2015:10) mengemukakan bahwa Pendidikan IPS adalah penyederhanaan atau adaptasi dari disiplin ilmu-ilmu sosial dan humaniora, serta kegiatan dasar manusia yang diorganisasikan dan disajikan secara ilmiah dan pedagogis psikologis untuk tujuan pendidikan. Dengan IPS kita ingin membentuk subyek didik, membentuk sosialnya agar ia mampu memahami dan memecahkan masalah-masalah sosial. Dari sudut disiplin ilmu pengetahuan, wujudnya memang memberikan konsep-konsep pengetahuan dari semua bagian disiplin IPS yang hubungannya dengan pemahaman dan pemecahan masalah-masalah lingkungan.

Menurut Desmita (2014:3) menyatakan bahwa peserta didik merupakan insan yang memiliki aneka kebutuhan. Kebutuhan itu harus tumbuh dan berkembang sesuai dengan sifat dan karakteristiknya sebagai manusia.

Adapun menurut Hamalik (2009:99) mengatakan bahwa murid adalah Salah satu komponen pengajaran, disamping faktor guru, tujuan dan metode pengajaran sebagai salah satu komponen yang terpenting di antara komponen lainnya. Pada dasarnya "ia" adalah unsur penentu dalam proses mengajar. Tanpa adanya murid, sesungguhnya tidak akan terjadi proses pengajaran. Peserta didik adalah individu yang memiliki berbagai 
macam kebutuhan dan memiliki karakter-karakter berbeda. Peserta didik merupakan sumber daya utama dan terpenting dalam proses pendidikan formal. Tidak ada peserta didik maka tidak ada guru. Peserta didik bisa belajar tanpa guru. Sebaliknya guru tidak bisa mengajar tanpa peserta didik. Sedangkan menurut Muhibbin Syah (dalam J. Robert Stenberg, 2008:141) mendefinisikan prestasi sebagai tingkat keberhasilan siswa dalam mencapai tujuan yang ditetapkan dalam sebuah program. Prestasi belajar merupakan hasil penguasaan materi yang telah diterima oleh peserta didik dalam proses belajar mengajar.

Berdasarkan fenomena yang disebutkan di atas, dapat dirumuskan tujuan dari penelitian ini adalah untuk mendeskripsikan persepsi tentang mata pelajaran IPS pada berprestasi rendah di SMP Muhammadiya Palangka Raya.

\section{METODE PENELITIAN}

Menurut Sugiyono (2007:1) metode penelitian kualitatif adalah: Metode penelitian yang digunakan untuk meneliti pada kondisi obyek yang alamiah, (sebagai lawannya adalah eksperimen) dimana peneliti adalah sebagai instrumen kunci, teknik pengumpulan data dilakukan secara triangulasi (gabungan), analisis data bersifat induktif, dan hasil penelitian kualitatif lebih menekankan makna dari pada generalisasi.

Penelitian ini menggunakan pendekatan kualitatif untuk mendeskripsikan secara mendalam dalam persepsi peserta didik tentang mata pelajaran IPS dan untuk mengetahui sejauh mana peserta didik memahami mata pelajaran IPS.

\section{HASIL DAN PEMBAHASAN}

Dari hasil wawancara kepada peserta didik hanya merasa wajib untuk mengerjakan tugas tetapi tidak diberikan nilai dari hasil yang sudah peserta didik kerjakan. Dan adanya ancaman bag peserta didik yang tidak mengerjakan tugas yang diberikan oleh guru berupa tugas mencatat materi ataupun tugas latihan di kelas dan tugas pekerjaan rumah (PR). Akhirnya peserta didik mengerjakannya dengan terpaksa dan mengakibatkan ketidaksukaan pada mata pelajaran IPS serta tidak maksimalnya peserta didik mengikuti proses pembelajaran.

Dari uraian pada temuan atau hasil penelitian di atas bahwa persepsi peserta didik yang mengikuti pelajaran IPS hanya terdapat beberapa saja. Dalam mata pelajaran IPS peserta didik bosan yang disebabkan karena peserta didik merasa terlalu banyak mencatat dan itulah yang membuat peserta didik sering ngobrol dengan teman-temannya dan tidak memperhatikan guru yang masuk di kelas.

1. Persepsi Tentang Mata Pelajaran IPS

Persepsi peserta didik tentang mata pelajaran IPS yaitu dimana disini peserta didik memberikan respon yang kurang suka dengan mata pelajaran IPS. Peserta didik merasa mata pelajaran IPS sangat membosankan dan sedikit sekali dari kata menarik dikarenakan guru yang selalu meminta peserta didik untuk mencatat yang terlalu banyak. Hampir semua peserta didik tidak menyukai 
mata pelajaran IPS hanya karena diminta oleh guru peserta didik untuk mencatat. Akan tetapi maksudnya disini yaitu dengan mencatat yang terlalu banyak, maka menimbulkan persepsi negatif peserta didik tentang mata pelajaran IPS.

2. Persepsi Tentang cara Guru Mengajar

Setiap guru memiliki cara yang berbeda-beda dalam mengajar, oleh sebab itu guru berhak mengatur lingkungan kelas sehingga peserta didik dapat melakukan proses belajar mengajar dengan efisien serta menjalin komunikasi yang baik dengan peserta didik. Kemampuan peserta didik untuk mengikuti mata pelajaran yang diberikan oleh guru tergantung dari cara guru mengajar. Tidak semua peserta didik memiliki daya tangkap yang tinggi, karena ada juga peserta didik yang merasa perlu bimbingan dalam proses pembelajaran.

\section{KESIMPULAN}

Cara guru mengajar yang selalu meminta peserta didik mencatat terlalu banyak serta guru kurang mampu melakukan pendekatan terhadap peserta didik yang berprestasi rendah. Jadwal mata pelajaran IPS yang ada pada siang hari sehingga peserta didik sudah merasa malas untuk mengikuti mata pelajaran IPS. Kurangnya perhatian guru terhadap peserta didik yang berprestasi rendah sehingga peserta didik merasa selalu jenuh pada saat pembelajaran IPS. Rasa bosan yang dirasakan peserta didik bisa dilebur dengan model pembelajaran yang baru. Serta melakukan pendekatan- pendekatan khususnya kepada peserta didik yang berprestasi rendah.

\section{DAFTAR PUSTAKA}

Desmita. 2014. Psikologi Perkembangan Peserta Didik. Bandung: PT Remaja Rosda Karya.

Hamalik, Oemar. 2009. Proses Belajar Mengajar. Jakarta: Bumi Aksara.

I Made Wirartha. 2006. Metodologi Penelitian Sosial Ekonomi.Yogyakarta: CV Andi Offset (Penerbit ANDI).

Sapriya. 2015. Pendidikan IPS. Bandung: PT. Remaja Rosda Karya.

Stenberg, J Robert. 2008. Psikologi Kognitif. Yogyakarta: Pustaka Pelajar.

Sugiyono. 2007. Metodologi Penelitian Kualitatif Sosial Ekonomi. Yogyakarta: Penerbit Andi.

Undang-Undang RI No.20 Tahun 2003 Tentang Sisdiknas. Yogyakarta: Media Abadi 